\title{
Bazı Örnekleriyle Başkanlık ve Yarı Başkanlık Rejimlerinde Kararname Uygulamaları: Karşılaştırmalı Bir Analiz
}

\author{
Volkan TURAN*, Cantürk CANER **
}

ÖZ

\begin{abstract}
Kararnameler, anayasa veya kanunlar çerçevesinde yürütme erkine verilen bağlayıcı bir düzenleme yetkisi olup, devlet otoritesinin doğal bir uzantısı olarak yürütme erki tarafından yerine getirilir. Parlamenter hükümet sistemlerinden faklı olarak başkanlık veya yarı başkanlık rejimlerinde bu yetki doğrudan devlet başkanına tanınmış olan güçlü bir kural koyma hakkı olarak değerlendirilmektedir. Rejimin niteliğine göre de uygulama biçimleri farklılık gösterebilir. İlaveten kararnamelerin yaptırım gücü, hukuk hiyerarşisi içindeki yeri de her ülkenin kendi anayasal düzeni içinde yerini bulmuştur. Bu çalışmanın amacı başkanlık ve yarı başkanlık rejimlerinde başkan veya hükümet tarafından çıkartılan kararnamelerin bazı ülke örnekleri içinde özellikleri, hukuk normları hiyerarşisindeki yeri, kullanılış biçimleri ve kullanım alanlarını karşılaştırmalı olarak ortaya koymaktır.
\end{abstract}

Anahtar Kelimeler: Başkanlık, Yarı Başkanlık, Kararname, Hükümet

JEL Sınıflandırması: H11

\section{Some Examples of Decree Implementation in Presidency and Semi-Presidency Regimes: A Comparative Analysis}

\begin{abstract}
Decrees are a binding regulatory authority granted to the executive within the framework of the constitution or laws and are fulfilled by the executive power. In presidential or semi-presidential regimes, this power is considered as a right to a strong rule that is directly attributed to the head of state, apart from parliamentary systems. Decrees may differ according to the nature of the regime. In addition, the power of sanctions and the place within the hierarchy of law were found in each country's constitutional order. The purpose of this study is to establish the hierarchy of the legal norms of the decisions taken by the president or the government in the presidential and semi-presidential regimes to make comparative use of the areas of use within the specifics of some countries.
\end{abstract}

Keywords: Presidential System, Semi Presidential System, Decree, Government

JEL Classification: H11

Geliş Tarihi / Received: 30.09.2020 Kabul Tarihi / Accepted: 24.11.2020

Doi: 10.17541\%optimum. 801969

\footnotetext{
* Dr. Öğr. Üyesi, Uşak Üniversitesi, Sosyal Bilimler Meslek Yüksekokulu, Yönetim ve Organizasyon Bölümü, volkan.turan@usak.edu.tr, ORCID: 0000-0001-6261-8816.

** Dr. Öğr. Üyesi, Kütahya Dumlupınar Üniversitesi, İIBBF, Siyaset Bilimi ve Uluslararası İlişkiler Bölümü, canturk.caner@dpu.edu.tr, ORCID: 0000-0002-4991-102X.
} 


\section{GİRİş}

Modern, demokratik ve hukuk devletleri içinde yürütme erkine verilen kararname hakk1 kaynağını esasen anayasadan alan bir yetkidir. Erkler ayrımının sert ve kesin hatlarla ayrıldığı başkanlık ve yarı başkanlık sistemlerinde kararnameler, düzenleyici, icrai karar alıcı ve yaptırım gücü olan yazılı kurallardır. Tarihsel olarak kararnameler ilk kez Antik Roma döneminde kullanılmıștır. Antik Roma'da kararname uygulamasına geçilmesinin nedeniyse idarenin özellikle ani veya esnek durumlarda kolayca icrai karar alabilmesidir. Bir başka deyişle Roma'da kararnameler idarenin hızlı bir şekilde karar alıp uygulanmasına imkân vermek için icat edilen kamu yönetimi uygulamalarıdır.

Günümüzdeyse yürütme erkinin başı olan cumhurbaşkanına (ya da başkana) tanınan kararname hakkının kullanım biçimi sistemin özelliklerine göre değişiklik göstermektedir. Başkanlı sistemlerinde kararnameler, yasa gücünde olup, doğrudan anayasal iradeyle kullanılırken; yarı başkanlık sistemlerinde de yine anayasal dayanağı bulunmakla birlikte bakanlar kurulu aracılı̆̆ıyla veya parlamento onayı sonucunda kullanılır. Kararname uygulamalarının parlamenter sistemlerde de kullanıldığı görülmektedir. Ancak parlamenter sistemlerde kararname uygulamalarının anayasal, yasal ve parlamento iradesi olmak üzere üçlü bir iradeye dayandırılmakta, olağan ve olağanüstü biçimde uygulanmaktadır.

Başkanlık veya yarı başkanlık sistemlerinde kararnameler olağan bir idari işlem olarak görülür. Bir başka deyişle bu tarz sistemlerde kararnameler idarenin rutin işleyişinde sıklıkla kullanılan düzenlemeler olup, diğer idari düzenlemelerin de üstündedir. Bir başka deyişle kararnameler idari mevzuatın en üstünde yer alan yazılı düzenlemelerdir. İşte bu çalışma başkanlık ve yarı başkanlık sistemlerinde yürütmenin en güçlü kural koyma ve uygulama aracı olan kararname kavramının özelliklerini, idare hukuku içindeki yerini ortaya koymayı amaçlamıştır.

\section{GENEL HATLARIYLA KARARNAME KAVRAMI VE HUKUK NORMLARI HIYYERARŞISIINDEKI YERI}

Bir kavram olarak kararname, gerek düzenleyen idareye, gerekse de işlevlerine göre çeşitleri olan ve bu isimle çıkarılan idari tasarruflara verilen genel bir tanımlamadır. Kararname yetkilerinin özü devlet yönetiminde yürütmeye işlerlik kazanmak ve kamu yönetimini daha etkin ve verimli bir şekilde işletebilmektir. Modern demokrasilerde kararnamelerin anayasal yetkilerden kaynaklanması beklenir. Bununla birlikte anayasalarda, açıkça kararname ismi verilen bir işlemin de mevcut olması beklenemez. Böyle durumlarda kararname dediğimiz işlem, kaynă̆ını açık bir şekilde anayasalarda bulmayan "geleneksel usuli" bir hukuki işlem olarak görülür (Kuzu, 1985: 135).

Kararnameler, nitelik ve işleyişi itibariyle idare hukukunun tartışmaya açık bir konusu olarak değerlendirilir. Zira kararnameler çoğu zaman hukuk yaratma veya daha ileri gidecek biçimde kanun üretme olarak algılanmaktadır. Özellikle konu, devlet başkanlığı meselesi üzerinden değerlendirildiğinde kararname yetkisi ve kullanımının erkler arasındaki dengeyi bozabileceği, yetki gaspına yol açacağı endişesi üzerinde yoğunlaşmaktadır. Oysa kararnameler aslında idarenin düzenleyici işlemlerinden başka bir şey değildir. Zira idare her zaman, sürekli olarak, soyut, nesnel ve herkesin uyması gereken hukuksal işlemler yapar. İdarenin düzenleyici işlemi olarak adlandırılan bu durum idarenin kararlarını doğrudan etkileyecek bir hususlar bütününden meydana gelmektedir.

İdarenin düzenleme yetkilerinin anayasalar ve kanunlara dayalı olması doktrinel ortak bir görüştür. Yani idarenin düzenleme yetkilerinin kaynağı anayasa, yasa ve diğer hukuk kurallarıyla sınırlı olmalıdır (Gözler, 2003: 308). Zira düzenleyici işlemler içerikleri bakımından 
kanunlar gibi norm koyucu işlemlerdir. Anayasa hukukunda idarenin düzenleyici yetkisinin alanı açıkça çizilmiştir. Bununla birlikte düzenleme yetkisinin sınırları da bulunmaktadır. Bu sınırlar, düzenleme yetkisinin yasa koyucu tarafından doğrudan veya dolaylı olarak ve sayma yoluyla verilmesi, bu yetkinin devredilemez bir yetki olmas1, yarg1 tarafindan denetlenebilmesi ve sınırlandırılabilmesidir (Gündüz, 2007: 754-755).

Ülkelere ve hukuk düzenlerine göre değişiklikler olmakla birlikte kaynağını anayasadan veya kanunlardan alan düzenleyici işlem türleri de genel olarak kararname, tüzük, yönetmelik, genelge, yönerge ve emir olarak sıralanmaktadır. Bunlara ilaveten karar, tebliğ, sirküler, statü, esaslar, genel emir, tenbihname, genel tenbih, ilan, duyuru, plan, tarife, ilke kararı, talimat ve iç düzen kararı gibi isimler taşıyan adsız düzenleyici işlemlere de rastlanır (Gözler, 2000: 407408). Her bir düzenleme biçiminin normlar hiyerarşisindeki yeri ve uygulanma yöntemleri de ülkelerin iç hukuk sistematikleriyle belirlenmektedir.

İdarenin düzenleyici işlemleri içinde en sık kullanılan bir enstrüman olarak kararnamelerin Kara Avrupası hukuk sisteminde ve Anglo Sakson hukuk sistemlerinde farklı bir temelden doğduğu görülmektedir. Kamu hukuku ile özel hukuku birbirinden ayıran Kara Avrupa sisteminde kararnameler olağan ya da olağanüstü durumlar için kullanılmaktadır. Olağan hallerde çıkarılan kararnameler daha çok bir kanunun nasıl uygulanacağı, hangi esaslar dahilinde yürütüleceğini düzenleyen somut kurallar veya uygulama biçimleri olarak değerlendirilir. Olağan dönemlerde parlamento, hükümete veya hükümet başkanına kararname yapma yetkisi vermekte, daha sonra çıkarılan kararnamenin yine parlamento tarafından kanunlaştırılmasına gidilmektedir. Olağan dönemlerde yapılan kararnamelerin yetki, konu, şekil, denetim ve diğer hususlar olmak üzere beş temel unsurdan meydana gelmesi genel bir kuraldır.

Olağanüstü dönemlerde çıkarılan kararnamelerin gücü ve etkinliğiyse ise yine anayasa mevzuatı içinde geçerli kurallara göre düzenlenir. Olağanüstü kararnamelerin diğerinden en önemli farkı geçici olarak temel hak ve özgürlüklerin kısmen veya tamamen durdurulmasına ya da vatandaşlar için bazı yükümlülüklerin getirilmesine imkân veren düzenlemeler yapılmasıdır (Gözler, 2000: 409-410). Bu bağlamda olağanüstü hal, sıkıönetim, genel seferberlik ve savaş halleri bu kararnamelerle yönetilmek durumundadır. Bununla birlikte olağanüstü hal kararnamelerinin olağanüstü halin şart ve esaslarına uygun olması da gerekli bir husustur (Aliefendioğlu, 1992: 413-414). Usul ve şekil bakımından olağanüstü hal kararnamelerinin olağan kararnamelerdeki esaslara uygun olması beklenir. Buna mukabil olağanüstü hal kararnamelerinin anayasal denetimi de bulunmaz. Olağanüstü hallerde çıkarılacak kararnamelerin tek denetim mekanizması yasama organıdır. Yasama bu tür kararnamelerin süresini ve kapsamını daraltabilir veya esaslarını belirleyebilir.

Teorik olarak Anglo-Sakson hukuk sisteminin de kararname konusunda Kara Avrupa hukukuyla aynı amacı taşıdığı görülür. Bununla birlikte Anglo-Sakson gelenek, kararname konusunda uygulamada farklı beklentiler içine girmiştir. Bilindiği üzere Anglo-Sakson hukuk sisteminde hukuk kuralları tek başına yasama etkinliğinin sonucu olarak ortaya çıkmış genel ve soyut düzenlemelerden meydana gelmez. Doğrudan sosyal hayatın pratiklerinden doğan somut olayların çözümlerini de içerir (AJGM, 1981: 198-199). Bu sistemde yargı kararları ve yürütme uygulamaları da hukuk üretmenin bir başka yöntemidir. Sistemin bu özelliği tamamıyla tarihsel ve geleneksel bir düşünce gelişiminin ürünüdür. Anglo-Sakson sisteminde idare hukuku kamu hizmetlerinin büyümesi sonucunda ortaya çıkmış, ceza ve özel hukukun dışında kalan bütün konuları içeren bir anlayışa sahip olmuştur (Berkarda, 2000: 89). Zaman içinde kamu yönetimini ilgilendiren bütün alanları kapsayacak şekilde genişlemiş, günümüzde kamu hizmeti olarak görülen bütün alanlarda faaliyet gösteren kamu ve özel sektöre ait kuruluşları denetleyen, yönlendiren ve kontrol eden bir mekanizmaya dönüşmüştür. Özellikle Amerikan idare hukukunun gelişmesiyle birlikte düzenleyici, arabulucu, istikrarı sağlayıcı ve icrai işlem yapan ancak dar bir anlama sahip hukuk sistematiği kendisini göstermiştir (Berkarda, 2000: 93). Genel 
hukuk sistemi içinde kendisine özgün bir yer bulan idare hukuku, Kara Avrupa sisteminde olduğu gibi farklı bir alana kaymamıştır. Tıpkı özel sektör gibi idareler de genel ekonomik ve sosyal düzen içinde genel hukuk kurallarına bağlıdır ve her türlü uyuşmazlıkta bütüncül bir yargı sisteminin denetimine tabidir. Sistemin genel özelliği içinde yargı, gerekli gördügünde iptal etme, yasaklama veya zorlayıcı emir verme olmak üzere çeşitli somut düzenlemeleri yapmak ve kural koymak gibi geniş bir hareket alanına sahiptir (Avcı, 2014: 170-171). Yargının diğer konularda olduğu gibi idare hukuku alanında bu denli etkin olmas1, Anglo-Sakson idare hukukunu, adli idare hukuk sistemi olarak tanımlanmasına yol açmıştır (Saygın, 2017: 61).

Anglo-Sakson hukuk sistemi içinde idarenin düzenleyici işlem yapma yetkisinin hukuki sınırlarının yargı üzerinden çerçeve içine alınması, uygulamada idareye kararname yapmasına engel teşkil etmez. Üstelik bu yetki idareye yargı erki tarafından açıkça tanınan haller için verilmiştir (Schwartz, 1952: 434). Ancak bu yetki biçiminin kapsamı ve alanı daraltılmış, daha çok özel ve somut olaylara yönelik olarak düzenleme yapma yetkisi olarak tanımlanmıştır. Bu yetkinin bir diğer özelliği de geçici bir yetki olmasıdır. Yasama ve yargı erkleri, idareye düzenlemelerini değiştirebilirler veya tümüyle kaldırabilirler. Dolayısıyla bu yetki çeşidi yeni bir düzenleme yapmaktan çok açıklayıcı veya tamamlayıcı bir yetki olarak değerlendirilir. Burada temel amaç idareyi devlet yönetiminin içine sokmak ve idarenin acil çözüm bekleyen konularına somut öneriler sunmaktır.

\section{KARARNAME YETKISIININ TARIHHSL GELIŞiMIMI}

Günümüz dünyasında devlet idaresinin önemli bir uygulama biçimi olan kararname yetkisinin doğuşunu Antik Roma'ya kadar indirmek mümkündür. MÖ. 44'te Sezar'ın Roma Senatosu'nda öldürülmesi, bu yetkinin pratikteki ilk uygulamasına sebep olmuştur. İktidarı ele alan Augustus, Mark Antony ve Aemilius Lepidus üçlüsü (II. Triumvirate) döneminde senato, fiilen işlemez hale getirilmiş ve Lex Titia adlı kararname çıarma yetkisi bu üçlünün eline geçmiştir. Lex Titia'nın özelliği senato yerine söz konusu üçlünün devlet yönetiminde bireysel veya ortak kararlar alabilmesi ve bu kararların kanun gücünde olmasıydı (Ando, 2013: 931-932). Ancak bu durum gerçekte cumhuriyetçi bir kanun yapıcılığından çok oligarşik bir emir ve kumanda yetkisini ifade etmekteydi. Üstelik üçlü oligarşinin sonsuz yetkisine dayandırılan bu yetki o dönem için ilk defa gündeme getirilmiş de değildi. Tam aksine Lex Titia'nın kaynağı MÖ. 111'de yani Roma'nın kuruluş dönemlerinde bir Romalı kentin ilk kuruluş kanuna dayandırılmıştı. Kısaca kuruluş, rıza ve ikamet olarak tanımlanan bu kurallar bütünü en eski hukuk normları olarak imparatorluğa bağlı bütün kentlerin ilk kabul etmeleri gereken bir "ex nihilo" (yoktan var olma, bir anda ortaya çıkma) hükümdü. İşte bu hükümler Lex Titia'nın oluşumunda temel bir kaynak olmuştu. Dolayısıyla Lex Titia imparatorluğu oluşturan kentlerin (elbette ki vatandaşları ve soylularıyla birlikte) üçlü oligarşiye koşulsuz ve şartsız bağlanması olarak görülmüştü (Ando, 2013: 932-933). Hiç kuşkusuz Roma Cumhuriyeti'nin böyle bir yönetim tarzı ve uygulamasına gitmesinin sebebi olağanüstü bir gelişmeden kaynaklanıyordu. Zira Sezar, senatoya girdiği sırada kendisine muhalif bir grup senatör tarafından acımasızca bıçaklanmıştı. Üstelik kendisini bıçaklayanlar, Roma'yı terk ederek bir ordu kurmak üzere harekete geçmişlerdi. İşte bu olağanüstü durum şartlarında üçlü bir yönetim modeli ve kararname geleneği "de facto" olarak, yani gerçek hayattaki uygulama biçimi olarak, doğmuştur. İmparatorluğu üç bölgeye ayıran oligarşi, senatodan aldığ yetkiyle kendi görev alanlarına giren bölgeleri yönetme hakkını ellerinde tutmuşlardır. Ancak Roma'nın olağan üstü hal (OHAL) şartlarındaki bu yönetim tarzı başka sorunların önünü alamamış, nihayet MÖ. 33-32 arasında "cumhuriyet" rejiminin sonunu getirerek Augustus İmparatorluğu'na dönüşmüştür.

Augustus'un kendisini tanrisal bir imparator olarak ilan etmesiyle birlikte Roma klasik bir monarşiye, Lex Titia ise zaman içinde monarşilerden, uygulanan kanunlara doğru dönüşüm gösterdi. Monarşilerin kanunu olan düzenlemeler ise nitelik ve bağlayıcılık bakımından 
kararnamelerden farklıydı. Bu farklılık ise monarşilerin anlam ve içeriğinden kaynaklanmıştır. Bununla birlikte 18. yüzyıldan itibaren monarşiler tartışmaya açılmış ve otoritesi sorgulanmaya başlamıştır. Anayasalcılık kavramı bu tartışmaların tam da ortasındadır ve bu kez halk egemenliği tartışmaları çerçevesinde sınırlandırılmak istenmektedir. Liberalizm ve sanayileşme ekseninde gelişen batı anayasalcılığı özellikle constitutio yani kurma, kuruluş kavramlarına odaklanmıştır (Oder, 2004: 27-28). Kanun yapma ve bu kanunlara uyma gibi konular ise kurulan bir sistemin uygulanma safhalarını ifade etmektedir. Kanunlar aynı zamanda yazılı hukuk kurallarının da anayasaya dayandırılacak temelidir. Devleti oluşturan bütün hukuk düzeni önce anayasaya, ardından kanunlara uygun olmalıdır. Batı düşünce dünyasında kısa sürede yerini bulan anayasalcılık kavramı 19. yüzyılda modern devletlerin kurulmaya başlamasıyla pekiştirilmiştir. $\mathrm{Bu}$ yüzyılda pek çok başarısız örneği olsa da anayasalar temel kuruluş metinleri olarak egemenliğin biçimsel meşruluk temellerini geleneğe göre değil, aksine pozitif hukuk kurallarına dayandıran bir sonuç belgesi olarak değerlendirilmişlerdir (Oder, 2004: 39-40).

Yüzlerce y1llık monarşi geleneğinin ardından 18. yüzyılda kararnamelerle ilgili iki önemli gelişme yaşanmıştır. Birbirine çok yakın ve birbirini tetikleyen bu iki gelişmeden biri ABD Bağımsızlık Bildirgesi diğeri de hemen sonrasında kıtayı etkileyecek olan Fransız İhtilali'dir. Bu iki olay, egemenlik kavramına doğrudan etkide bulunan sanayileşme öncesindeki köklü bir dönüşümün temsilcileridir. Zira her iki dönüşüm de monarşileri bir şekilde geriletip, yerine cumhuriyet rejimlerini öne çıkarmayı başarmıştır. Teoride ve pratikte yeni düşünce akımlarını da bu iki gelişme, kararname konusuna da özgün bir yaklaşım getirmiş̧ir. Şöyle ki, ABD Bağımsızlık Bildirgesi, Yeni Dünya'da monarşiyi kovmuş ve yerine özgün bir cumhuriyet ile devlet fikrini ortaya atmıştır. Bu özgün devlet ise federalizme dayalı ve erkler ayrılığını tam olarak esas alan pragmatik bir yönetim biçimidir. Yasama erkine verilen kanun yapma gücü, zaman içinde yürütme erkine kararname çıkarma yetkisiyle denetlenmiştir. Böylece ortaya birbirini tamamlayan iki hukuki düzenleme çıkarılmıştır. Yargı erki ise her iki düzenlemeyi de kontrol eden ve denetleyen üçüncü bir güç olarak kendisini göstermiştir. Amerikan devlet sisteminin en önemli özelliği esnek ve kendisini kolayca yenileyebilen mekanizmalardan meydana gelmesidir.

Fransız İhtilali ise Kıta Avrupası'nda ortaya çıkan cumhuriyetçi dönüşümün temsilcisi olarak bilinmektedir. Ancak Fransız modeli Yeni Dünya'daki emsalinden daha sancılı ve karmaşık bir gelişme göstermiştir. Nitekim 1789 Fransız İhtilali, başından itibaren birbiriyle bağıntılı olaylar dizisinden ve iç içe geçmiş ara devrimlerden meydana gelen bir dönemdir. Başlangıçta iktidarı ele geçiren Jakobenler, mutlak iktidarı ellerine alacak kudret ve güçten yoksun olduklarından yaptıkları anayasayı yürürlüğe sokmaktan kaçınmışlardır. Devrimin yasama erkini temsil eden konvansiyon ise yetkilerini Kamu Selameti Komitesi (Le Haut Comite de Salut Public)'ne devretmiştir (Ekinci, 2016: 160). Robespierre diktasının hukuki dayanağını temsil eden Komite 1795'e kadar doğrudan, bu tarihten 1799'a kadar da Direktuvar Kurulu aracılığıyla ülkeyi "kararnamelerle" yönetmiştir. Her ne kadar literatürde Direktuvar Rejim'in çıkardığ 1 kararlar kanun olarak adlandırılmaktaysada, dönemin Fransız parlamentosunun askıya alınmış olması, yapılan bu düzenlemeleri kanun olmaktan öteye taşımıştır. Söz konusu dönem literatürde aynı zamanda "devlet terörü dönemi” olarak da adlandırılmaktadır. Çünkü Direktuvar Yönetimi, beş kişiden oluşan ve dönemin olağanüstü şartlarını yönetmeye odaklanan bir iktidar biçimidir. Nitekim bu dönem başka bir devrime yol açarak yerini Napolyon idarelerine bırakmıştır. Fransız İhtilali, diğer sonuçlarıyla birlikte Kıta Avrupası'nda olağanüstü yönetim modelini de sokmuş, yeni bir iktidar model ortaya çıkarmıştır. İşte Fransız toplumunun içinde bulunduğu olağanüstü şartlar kararname uygulamasını sebep ve sonuçları açısından olağanüstü hal çerçevesinde yürürlüğe sokmuştur.

Kararname uygulamalarının 20. yüzyılda ilk örneğinin ise Sovyetler Birliği olduğu söylenebilir. Bu bağlamda ilk Sovyet kararnamesi 26 Ekim 1917'de Bolşevikler tarafından yayınlanmıştır. Rus monarşisine karşı köylü, işçi ve bürokrasi sınıfını ihtilale çağıran kararname, 
ihtilalin başarıya ulaşmasından sonra çıkarılan 8 Kasım 1917 Barış Kararnamesi (Decree on Peace) ve 19 Şubat 1918 Arazi Kararnamesi (Decree on Land) ile kalıcı bir uygulama olarak yerleşmiştir (Lenin, 1917). Daha sonraki yıllarda Sovyet kararnameleri Sovyet kongreleri tarafından kabul edilip yürürlüğe sokulmuştur. II. Dünya Savaşı boyunca Stalin bu yetkiyi tekeline almış, ölümünden sonra Polit Büro eliyle yürütülmüştür. Sovyetlerin dağılmasından sonra doğrudan Rusya Devlet Başkanı'nın uhdesine bırakılan kararname geleneği halen büyük ölçüde kullanılmaktadır.

1930’lu yıllarda Nazi Almanyası'nın da ülkeyi kararnamelerle yönettiği söylenebilir. Kararname yetkisinin en keskin ve en kötü örneğini temsil eden Nazi kararnameleri, kısa zamanda belirli bir düzen içinde işleyen Alman hukuk sistemini sarsmış ve kötü etkilemiştir. Nazi yönetimi sadece sebep olduğu terör faaliyetleriyle değil, aynı zamanda kurduğu hukuk düzeniyle de karanlık bir dönemi ifade eder. 30 Ocak 1933'te Almanya iktidarını ele alan Naziler, Hitler'in başbakanlığa getirilmesinin hemen ardından 27 Şubat 1933 yılında Reichstag yangını bahane ederek Halkın ve Devletin Korunması için Reich Devlet Başkanı Kararnamesi (Reischtag Yangın Kararnamesi) adlı ilk kararnamelerini yayınlamışlardır. Özetle Alman Reich Anayasası'nın 42. maddesine dayanarak cumhurbaşkanına verilen ve parlamentoya danışmaksızın acil tedbirler alma yetkisi dahilinde çıkarılan bu kararnameyle, yine anayasanın 114, 115, 117, 118, 123, 124 ve 153'üncü maddeleri açıkça askıya alınmıştır. Bu sebeple, kişi, basın, örgütlenme ve toplanma özgürlükleriyle posta, telgraf ve telefonla yapılan iletişim gizliliği de dahil pek çok alanda ciddi yasaklar getirilmiştir. Hatta kararnameyle birlikte hükümete, parlamento dahil tüm kamu ve özel kuruluşlarda arama yapabilme, her türlü malı müsadere edebilme ve mülkiyet haklarını ulusal güvenlik tehdidi nedeniyle sınırsızca kısıtlayabilme yetkisi tanınmıştır (World Future Fund, 2020). Bu kararnameyle iktidarı kesin bir şekilde ele geçiren Naziler, İkinci Dünya Savaşı yılları boyunca Almanya'yı Führer kararnameleriyle yönetmişlerdir.

İkinci Dünya Savaşı’ndan sonra kurulan Yeni Dünya Düzeni içinde kararnameler hızla yaygınlaşmış ve çeşitlenmiştir. $A B D$ ve Sovyet modellerinde görüldüğü üzere yürütmeye tanınan kararname yetkisi, modern dünyanın kalıcı bir düzenleme uygulaması haline dönüşmüştür. Halen günümüzde pek çok ülke kendi idari sisteminde çeşitli hukuk hiyerarşisi içinde kararname çıkarmakta ve bunu uygulamaktadır. Batı demokrasilerinde kararnameler yargının doğrudan denetimine açık, şeffaf ve somut düzenlemeler olarak kendisini gösterirken, az geliş̧miş toplumlarda devleti yöneten kadroların elinde otoriter veya totaliter hukuk kuralları olarak kendisini göstermektedir. Bu örneklere de bakarak kararname yetkisinin gerçekte yürütme erkinin doğal bir uygulanma biçimi olduğunu, anayasal bir yetkiden kaynaklandığını, olağan ve olağan üstü konularda düzenlendiğini söylemek mümkündür. $O$ halde temel sorun kararnamenin varlı̆̆ 1 ya da zorunluluğunu tartışmak değil, aksine hukuk normları hiyerarşisi içinde nerede durduğunu ortaya koyabilmektir.

\section{DÜNYA UYGULAMALARINDA KARARNAMELER}

Günümüz postmodern dünyasında kararnameler, küresel dünya koşullarının etkisiyle hızla değiş̧en siyasi konjonktürlere idarenin ayak uydurabilmesi ve hızlı karar alabilme çabası olarak değerlendirilmelidir. Kararname uygulamaları ülkeden ülkeye değişiklik göstermektedir. Her ülke kendi tarihi geçmişi, özgün dinamikleri, siyasi ve idari yapısı çerçevesinde farklı kararname içeriğine sahiptir. Dolayısıyla tek ve bütün yönleriyle başarılı bir kararname biçiminden söz etmek mümkün değildir.

Başkanlık sistemlerinde kararnameler hem yürütmenin hem de devletin başı olan başkan tarafindan doğrudan kullanılabilen bir yetkidir. $\mathrm{Bu}$ yetki, doğrudan anayasa veya yasalara dayanmakta, ya da yargı erki tarafından verilmiş bir hak olarak tezahür etmektedir. Başkanlık 
sistemlerinde kararname uygulamalarının en belirgin örneğini ise $A B D$ Başkanlık Kararnameleri oluşturmaktadır. Teorik anlamda ABD'de başkanın kararname çıkarma yetkisinin esasen bulunmadığı kabul edilir. Ancak bu kabul, esasen ABD anayasa hukukunun kuramsal tartışmalarından kaynaklanır. Oysa günümüze kadar geçen sürede ABD başkanlarının 1262'si numaralandırılmamış, 5.855'i numara dışı ve 13.817 numaralandırılmış toplam 19.672 adet kararname çıkardıkları görülür (The American Presidency Project, 2020). Demek oluyor ki, başkanlık kararnameleri ABD’nde sıklıkla başvurulan bir karar alma yöntemidir. İlk başkanlık kararnamesi 1793 yılında George Washington tarafından yayınlanmıştır. İngiltere ve Fransa arasındaki savaşta konfederasyonun tarafsız kalacağına dair çıkarılan bu kararname, sadece niyet beyanından ibarettir. Amerikan tarihinde ilk güçlü ve icracı kararnamenin ise 1862 'de Philedelphia Yüksek Mahkemesi'nin Başkan Lincoln'e verdiği yetkiyle çıkartılan kararname olduğu kabul edilir (Dirk, 2007: 102). Zaman içinde gelişme gösteren başkanlık kararnameleri özellikle II. Dünya Savaşı öncesinde ve Başkan Roosevelt'in ikinci döneminde, Beyaz Saray bünyesinde kurumsal bir yapı bünyesinde çıkarılmaya başlanmıştır. Resmi adı Executive Office of the President of the United States (Birleşik Devletler İcra Ofisi) olan bu kurum, halen ABD başkanının çıkardığı kararnameler ve kendisine verilen diğer görevleri yerine getirmektedir. ABD'nde başkanlık kararnameleri Presidential Orders (Başkanlık Emirleri) başlığı altında ele alınır (Clifford, Vaughan ve Baker, 1944: 6).

Başkanlık emirleri de kendi içinde iki ana kategoride değerlendirilmelidir. Birinci kategori, kanun gücünde ve hukuk koyucu özelliğe sahip icracı kararnameler (Executive Legislation- Yürütme Yasası) olarak tanımlanabilir. Bu kategoriye Executive Orders, Presidential Memoranda ve Regulations'ları yerleştirmek mümkündür. Executive Orders, ABD başkanı tarafından çıkartılan ve Birleşik Devletler Federal Hükümeti'nin görevlilerine ve ajanslarına yönelik doğrudan emirler olarak tanımlanır (Chu ve Garvey, 2014: 1). Bu emirler özelliği itibariyle icracı emirlerdir, tüzükten veya anayasanın kendisinden türetilen otoriteye dayanan tam bir hukuk gücüne sahiptir. Bu tür emirleri yapma kabiliyeti aynı zamanda, başkana bir dereceye kadar takdir yetkisi (delegated legislation) delege eden, açık veya zımni kongre yasalarına dayanmaktadır. Bir başka deyişle Executive Orders lar ancak kanunlarla veya yüksek mahkeme kararlarıyla değiştirilebilir, kaldırılabilir veya sınırlandırılabilir. Oldukça geniş bir düzenleme alanı olan bu kararname biçimi literatürde en yaygın incelenen hukuki metinlerdir. Presidential Memoranda (President Memorandum) ise, başkanlık mutabakat metni veya başkanlık muhtırası olarak tanımlanır. Hiyerarşide ikinci sırada yer alan Memoranda, Federal idari sistem içinde bulunan bakanlıkların, çeşitli departmanların veya ajansların eylemlerini, uygulamalarını ve politikalarını yönetmek üzere doğrudan başkan tarafından yayınlanan bir tür yürütme eylemidir (Korte, 2017a). Executive Orders'lar kadar bilinmese de siklıkla kullanılan Memoranda'lar çoğunlukla atama, bir faaliyeti onaylama veya bir kuralın nasıl uygulanacağını göstermek üzere çıkartılır. Executive Orders'lardan farklı olarak Resmi Gazete'de numaralandırmaksızın yayımlanırlar ve yine başkan tarafından başka bir Memoranda ile değiştirilebilir ya da yürürlükten kaldırılabilir. Regulations ise teorik olarak bir kanunun nasıl uygulanacağını göstermek, ya da içeriği geniş olan kanunun hangi usuller veya esaslar doğrultusunda ele alınacağını göstermek amacıyla yapılır (National Archieves, 2020). Diğer düzenlemelerden farkı daha sonra parlamentoda kanunlaşmasıdır. Bununla birlikte Regulations'ların uygulamada daha farklı biçimde kullanıldığ 1 görülmektedir. Midnight Regulations (Gece Yarısı Düzenlemeleri) adı verilen bu uygulama biçimi başkanın görev süresinin bitimine yakın yeni gelen başkana ve parlamentoya yönelik önceden belirlenmiş politik hedeflere ulaştırma çabası olarak tanımlanmaktadır (Carey, 2012: 1). Bu yönteme yine Amerikan siyaset literatüründe "Cinderella etkisi" denmektedir.

ABD başkanlarının çıkardığı ikinci grup kararname ise idari düzenlemeleri ifade eden ve bizim hukukumuzda yönetmelik, yönerge veya emir olarak tanımlanan bağlayıcı, fakat hiyerarşide ikinci grupta yer alan düzenlemelerdir. Bir başka deyişle bu gruba Presidential 
Directives (Başkan Direktifleri) girmektedir. $\mathrm{Bu}$ düzenlemeler arasında Presidential Determination ve Presidential Proclamation say1labilir. Presidential Determination, federal hükümetin izlediği resmi bir politika ya da belirli bir konuda izlediği/izleyeceği konumu belirten bir düzenlemedir (Relyea, 2008: 4). Genellikle bir olayın vuku bulmasından sonra düzenlenirler ve özel emirler içerebilirler. Presidential Proclamation ise başkanın kamu politikaları konusunda yayımladığı bildirilerdir. Kamusal bir politikanın uygulanmasında izlenecek yol ve yöntemler veya bu konuda çıkarılmış düzenlemelerin nasıl uygulanacağını belirten direktifler olarak tanımlanmaktadır (Korte, 2017b). Resmi Gazete'de yayımlandıktan sonra yürürlüğe giren Proclamation'lar uygulamada törenler ve milli günlerin belirlenmesi veya daha somut ve özel konularda çikarılırlar.

Başkanlık kararnameleri konusunda bir başka çarpıcı örnek ise Rusya Federasyonu'dur. Rusya'nın başkanlık mı veya yarı başkanlık rejimine mi tabi olduğu konusu tartışmalı bir konudur. Literatürde bu konuda tartışmalar halen devam etmektedir. Federasyon başkanının yanı sıra başbakana sahip olması ve her ikisinin farklı yetkiler taşıması nedeniyle yarı-başkanlık rejimine sahip olduğu konusu daha ağır basmaktaysa da başkanın yetkilerine bakıldığında başkanlık rejimine sahip bir ülke olduğu kanaati hâsıl olmuştur. Rusya Federasyonu'nda kararname yetkisi doğrudan başkana tanınan anayasal bir yetkidir ve kanuni sınırları dahilinde kullanılır (Remington, 2000: 509). Kisaca Ukaz (Үказ-Ukase) olarak adlandırılan bu kararnameler, Çarlık döneminde ilk defa kullanılmış, Sovyetler Birliği’nde de uygulanmış ve günümüze kadar gelmiştir. Ukase, herhangi bir bildiri ya da kararname, nihai ya da rasgele bir konunun düzenlenmesi anlamına gelir. Bir başka deyişle bu yetki anayasa tarafından açıkça tanımlanmış, olağan ya da olağanüstü durumlarda doğrudan başkan tarafından kullanılan devredilemez bir yetkidir (Rusya 1993 Anayasas1, 2020) (md.90). Zira anayasaya göre başkan, erkler üstü bir konumda görülmektedir (Erdem, 2017: 194). Buna mukabil, normatif hukuk hiyerarşisinde yerini alan Ukaz'ların uluslararası anlaşmaları, anayasa hükümlerini, federal veya federe parlamentolar tarafından çıkarılan kanunları değiştirme yetkisi de bulunmaz. Bunun yerine Ukaz'lar, doğrudan kural koyma yetkisinin yanı sıra idari ve siyasi atamalarda da kullanılabilen oldukça geniş bir yetki biçimidir (Remington, 2014: 82-87). İdari anlamda kullanılan yetkiler üst düzey kamu görevlilerinin atanması, başkomutanlık görevleri, hükümetin kurulması ve koordine edilmesi gibi konulardan oluşurken, siyasi anlamda kullanılan yetkiler yüksek yargı mensuplarının parlamentoya teklifi, dış politikanın yönetilmesi, Duma'nın şartlı fesihi, sıkıyönetim ve OHAL ilanı, referanduma gidebilme gibi oldukça geniş bir perspektife dayanır. Ancak, başkanın kararname yetkisi sınırsız da değildir. Aksine çerçeve içine alınmıştır. Federal bütçe, vergi ve harçlar, finans, kur, kredi ve gümrük, para konuları ile vatandaşlığın kazanılması ve kaybedilmesi, temel hak ve hürriyetler, idari yapı, seçim kuralları gibi özel konular sadece federal kanunlarla düzenlenebilir (Erdem, 2017: 197). Üstelik kanunla düzenlenen her konuda Ukaz değil, kanun hükümleri geçerlidir.

Rus devlet geleneği içinde Ukaz'lar dışında da başkana verilen bazı kararname yetkileri de bulunmaktadır. Bunlardan biri Postnanovlenie (Nостановление- Resolution)'dir. Kararlar olarak da ifade edilebilen bu kararname biçimi daha çok kamu bürokrasisinin işleyişi üzerine çıkarılan kurallardır (The Russian Governments, 2020). Bir diğeriyse Rasporyazheniye (распоряжение- Ordinance)'dir. Kısaca Yönetmelik olarak bilinen bu düzenleme biçimi başkan veya başbakan tarafindan çıkarılan, kanunların düzenlenişi ve uygulama biçimlerini ortaya koyar (Remington, 2014: 61 ve 63).

Latin Amerika'nın en büyük ve en kalabalık nüfusuna sahip ülkesi Brezilya, hem bölgesinde hem de dünyada başkanlık sisteminin özgün örneklerinden birisidir. 1988'de kabul ettiği başkanlık temelli yeni bir anayasayı kabul eden Brezilya, erklerin birbirinden bağımsız ancak dengeli ve birbiriyle uyumlu olmasına yönelik bir devlet sistemini öngörmüştür (Rosenn, 2009: 850). Brezilya 1988 Anayasas1 etkin ve güçlü bir yürütme sistemini öngörmektedir. Buna mukabil yürütme erki parlamentoya karşı sorumlulukla donatılmıştır. İşbirlikçi başkanlık olarak 
da tanımlanan bu sorumluluk biçimi çerçevesinde Brezilya 1988 Anayasası'nın (2020) 62. ve 84. maddeleri uyarınca başkana kararname yetkisi tanınmıştır (De Paula, 2016: 332). Medida Provisória (Provisional Measures, Geçici Tedbir) olarak adlandırılan bu yetki biçimi içeriği ve kullanışı bakımından dünyadaki diğer örneklerinden ayrılır. Medida Provisória başkana acil durumlarda veya konunun özelliği gereği derhal yapılması gereken konularda verilen bir kararname biçimidir. anayasa gereği bu kararname biçiminin 60 gün içinde parlamento tarafindan onaylanması gerekir. Bu süre içinde kabul edilmeyen kararnameler en fazla 60 gün daha uzatılabilir. $\mathrm{Bu}$ sürelerin sonunda parlamento tarafindan onaylanmayan kararnameler geçerliğini kaybeder (Rosenn, 2009: 847).

2001 yılında yapılan anayasa değişikliğiyle başkana bazı konularda kararname çıkarma yetkisi elinden alınmıştır. Bu konular ise vatandaşlık ve siyasal haklar, siyasi parti ve seçim kanunları, ceza ve ceza usul hukukuyla medeni usul hukuku, yargıyla ilgili konular, kalkınma planları, bütçeleme, bütçe direktifleri, bütçe ilave ve destekleri, krediler, mülkiyet hakları, finansal varlığa el koyma, tamamlayıcı kanuna ihtiyaç duyulan her türlü konular, parlamento tarafindan kabul edilen ancak başkan tarafindan henüz onaylanmayan veya veto edilen düzenlemelerdir (Solak, 2017: 222-223). Teoride zayıflatılmış bir yetki olarak görülse de Medida Provisória uygulamada, oldukça güçlü bir yetki biçimidir. Güçlü olmasının bir nedeni hem başkana hem de parlamentoya tercihte bulunma veya birbiriyle uzlaşma zorunluluğu sunmasıdır. Zira iptal edilen her kararname yasamaya ilave yükler doğurabilir (Solak, 2017: 228 ve Negretto, 2004: 535). Başkan kararnamelerinin bir başka gücü de kamu politikalarının uygulanmasından kaynaklanmaktadır. Teknik olarak olağanüstü durumlarda da çıkarılabilmekle birlikte hükümetin gündeminin belirlenmesi, idarenin yürütülebilmesi nedeniyle sıklıkla yayımlanmaktadırlar (De Paula, 2016: 364).

Tıpkı Rusya'da olduğu üzere başbakanlık makamının bulunması nedeniyle bazı kaynaklarda Azerbaycan yarı-başkanlık rejimleri arasında sayılmaktadır. Buna mukabil Azerbaycan modelini süper başkanlık veya patronal başkanlık olarak tanımlayanlara da rastlanmıştır. Başkanlık rejimiyle yönetilen Azerbaycan'da kararnameler, başkana tanınan özel ve anayasal bir yetki çeşididir ve kaynağını güçler ayrılığının katı bir biçimde ayrışmış olmasından alır. Azerbaycan 1995 Anayasası'nda yasama ve yürütme arasındaki yetki ve görev alanları açı bir dille belirlenmiştir. Nitekim anayasanın 93, 94, 95 ve 96. maddelerinde yasama erkinin, görev alanı, 109, 110, 111, 112 ve 113. maddelerinde yürütmenin görev alanları kesin sınırlarla hükme bağlanmıştır (Azerbaycan 1995 Anayasası, 2020). Bu yönüyle 1995 anayasası, yürütme erkini daha belirginleştiren, daha fazla öne çıkaran bir düzenleme görüntüsündedir. Anayasaya göre Azerbaycan Devlet Başkanı'nın kararname yetkisi 113. maddede iki ana başlık altında belirtilmiştir. Bütünüyle düzenleyici bir işlem olan kararnamelerden ilki Ferman, ikincisi de Serencam olarak adlandırılmaktadır. Fermanlar genellikle parlamento tarafından çıkarılan kanunların uygulanma biçimlerini göstermek üzerine çıkarılan kararnamelerdir (Mehmetoğlu, 2010: 90). Kanunlardan faklı olarak fermanlar normatif veya gayri normatif niteliktedir. Normatif fermanlar, kanunlar gibi hukuki bir normu ifade eder ve genele bağlayıcıdır. Gayri normatif fermanlar ise hukuki düzenlemelerin uygulanmasıyla ilgili olup, belirli kişiler hakkında veya verilecek ödüller gibi özel konularla ilişkilidir. Fermanların yürürlüğe girmesi için parlamento tarafindan onaylanması gerekir (Haciyev, 2009: 128). Serencam (Order-Emirname) ise başkanın özel bir konuyla ilgili verdiği kararname çeşididir (Aliyev, 2010: 74). Çoğunlukla bazı kamu görevlilerinin atanması veya ödüllendirilmesinde kullanılan serencamlar doğrudan yürürlüğe girerler.

Anayasanın 149. maddesi gereğince fermanların anayasa ve kanunlara aykırı olmaması zorunludur. İlaveten fermanlar veya serencamlara yapilacak itirazlar ise Anayasa yargis1 tarafından çözümlenir (Azerbaycan 1995 Anayasası, 2020, (md.130) ve Aliyev, 2010: 71). Ne var ki başkanın yayımladığı serencamların yargısal işlemleri konusunda da belirsizliğin bulunduğunu da eklemek gerekir. Anayasanın 113. maddesinde serencamlardan söz edilmesine 
ve 130. maddesinde de Anayasa Mahkemesi'ne denetleme yetkisinin açıkça verilmesine karşın, 148. maddede normatif hukuk kuralı içinde görülmemiş, "merkezi yürütme organının normatif düzenleri" içinde tanımlanmıştır. Anayasa hükümleri içindeki çelişkili ifadelerden dolayı serencamların hukuki denetimi konusunda ciddi bir belirsizlik bulunmaktadir (Aliyev, 2010: 74).

Yönetim yapıları içinde en özgün sisteme sahip olan Fransa'da yürütme cumhurbaşkanı, başbakan ve bakanlardan oluşan bir hükümet sistemine sahiptir. Gelişen şartlara bağlı olarak 1958 Anayasası'nda zaman içinde önemli değişiklikler yapılması sonucunda cumhurbaşkanı yürütmenin en önemli aktörü konumuna yükselmiştir. Bunun sonucunda yarı başkanlık adı verilen bir sistem doğmuştur. Kısaca yürütmeyi iki başlı bir yapıdan oluşturan bu sistemde cumhurbaşkanının belirleyici bir ağırlığı bulunurken, başbakana da bu ağırlığın hem taşıyıcısı hem de dengesi görevi yüklenmiştir. Fransız yönetim sisteminde cumhurbaşkanı ve başbakan arasındaki denge, 1958 Anayasası'nda pek çok noktadan kurulmuştur. Örneğin, cumhurbaşkanı yürütmenin sorumsuz kanadını oluştururken, parlamentoya karşı sorumluluk başbakana ve bakanlara aittir. Yine anayasaya göre cumhurbaşkanı istediği kişiyi başbakan olarak atayabilirken, bakanların atanmasında veya görevden alınmasında başbakanın onayına ihtiyaç duymaktadır (Fransa 1958 Anayasası, 2020) (md.8). Yine anayasaya göre cumhurbaşkanının kanun tasarısı yetkisi de yoktur. Yerine başbakan veya bakanlar bu görevi üstlenirler (Fransa 1958 Anayasas1, 2020) (md.89).

Anayasa, yürütme içindeki dengeyi sadece belli konularla da sınırlamaz. Décrets Lois (Statuary order-Yasa Gücünde Emirler) adı verilen kararname çıkarma yetkisinde de benzer bir denge mekanizması öngörülmüştür. Tam anlamıyla bir kararname olan décrets lois'ler yasa gücünde kararnameler olarak tanımlanan kural koyucu bir yetki biçimidir. Anayasanın 13. maddesine göre olağan dönemlerde cumhurbaşkanının doğrudan décret lois yetkisi bulunmaz. Tam tersine décret lois, cumhurbaşkanı başkanlığında toplanan hükümetle birlikte çıkartılan bir yetki türüdür (Yücel, 2003: 350). Bir başka deyişle Fransa'da cumhurbaşkanları tarafindan çıkarılacak olan kararnamelerde hükümetin de imzası gerekmektedir. Buradaki tek istisna başbakanın ilk ataması ile üst düzey kamu görevlilerin atanmasıyla ilgili kararnamelerdir. Ancak bu durum cumhurbaşkanına sıradan bir işlemi formaliteden yerine getirme olarak değil, hükümetin baş1 olarak bakanlar kurulunu yönlendirme ve kendi görüşlerini empoze etme olarak kullanılmaktadır (Oytan, 1982: 88).

Parlamento medeni haklar, borçlar, ticaret ve ceza hukukunu ilgilendiren konular, vergi ve para basımı, vatandaşlık işleri, yerel yönetimler, seçimler, kamu görevlilerinin özlük hakları, millileştirme, özelleştirme ve kamulaştırmalar, milli savunma, eğitim, çevre, çalışma, sendikalaşma, sosyal güvenlik hakları ve her türlü kamu maliyesine ilişkin konularda tam yetkilidir. Dolayısıyla bu alanlarda kanuni düzenlemeler yapılması anayasal bir zorunluluktur. Décret lois, ise anayasanın 34. maddesinde sayma yoluyla düzenlenen bu konuların dışında çıkartılan bir kararname biçimidir. Üstelik bu durum anayasanın 37. maddesinde de açıkça belirlenmiştir. Nitekim bu hükme göre parlamentonun yasama yetkisinin bulunmadığı bütün durumlar için kararname çıkarılabilir. Ancak yine aynı hükme göre Anayasa Konseyi'nin görüşü alınmak durumundadır.

Bununla birlikte anayasanın 16. maddesinde sayılan olağanüstü haller durumu saklıdır. $\mathrm{Bu}$ haller; cumhuriyetin kurumları, milletin bağımsızlı̆ğ, ülkenin bütünlüğü veya uluslararası taahhütlerin yerine getirilmesinin ciddi ve ani biçimde tehdit edildiği ve anayasal kamu güçlerinin düzenli işleyişi bozulduğu durumlardır. Söz konusu maddeye göre cumhurbaşkanı, olağanüstü hallerde başbakan, meclis başkanları ve anayasa konseyinin resmi görüşünü aldıktan sonra ülkede olağanüstü hal ilan etme yetkisine sahiptir. Olağanüstü yönetime geçildikten sonra cumhurbaşkanı hem kural koyan, hem de uygulayan bir makama dönüşerek décret lois çıkarma yetkisine sahip olur (Şencan, 2017: 44). Cumhurbaşkanının fesih yetkisi olağan dönemlerde sadece Millet Meclisine yöneliktir. Senatoyu feshetme yetkisi bulunmaz. Olağanüstü hal 
boyunca ise cumhurbaşkanının çıkardığı her türlü yetki yasama denetimi dışında tutulur. Yasamanın sadece olağanüstü hali uzatma veya kaldırma gibi yetkisi bulunmaktadır. Ayrıca bu dönem içinde cumhurbaşkanının parlamentoyu feshetme yetkisi de yoktur. Olağanüstü hal dönemlerinde cumhurbaşkanı yetkilerini tek başına kullanırken, Sıkıyönetim ilanı söz konusu olduğunda bakanlar kurulu kararıyla birlikte hareket etmek durumundadır (Fransa 1958 Anayasas1, 2020) (md.32).

Décret lois'ler dışında Fransız idari sistemi içinde cumhurbaşkanı ve hükümetinin çıkarabildiği başka kararnamelere de rastlanmaktadır. Bu kararnamelerden biri parlamento tarafindan hükümete verilen yetki kanununa dayanılarak çıkarılan Les Ordonnances (Rule by Decree-Kanun Hükmünde Kararname)'lerdir (Şencan, 2017: 55). Anayasanın 38. maddesinde hükümet programının uygulanabilmesi amaciyla parlamentonun düzenleme alanına giren konularda kanun çıkarılana kadar geçerli olmak üzere ve Danıştay görüşü alındıktan sonra yürürlüğe giren düzenlemeler les ordonnances olarak tanımlanır. Bu kararname biçimi hükümet tarafindan kanun tasarısıyla birlikte yürürlüğe girer. Bir başka deyişle hükümet kanun tasarısını ve les ordonnances' 1 birlikte hazırlar. Karşıllğında parlamentodan yetki ister. Parlamento tasarıyı görüşüp karara bağlayana kadar bu kararnameler yürürlükte kalır. Tasarının kanunlaşmasıyla kararname yürürlükten kalkar ve yerini kanuna bırakır (Vie Public, 2020).

Fransız idari sistemi içinde anayasa tarafından hükümete tanınan bir diğer kararname biçimi de Normes Réglementaire (Regulations-Düzenleyici İşlemler)'dir. Fransız normlar hiyerarşisinde üçüncü sırada yer alan ve yetki kanununa gerek duymaksızın çıkarılan bu kararname türleri bütün halinde idarenin özerk ve geniş düzenleyici işlemler sınıfına girerler (Şencan, 2017: 55). Tüzük veya yönetmelikler olarak da tanımlanabilecek bir yetki biçimi olan Normes Réglementaire'ler, anayasanın 37. maddesine dayanılarak çıkarılan düzenlemelerdir ve halk dilinde déecrets veya arrêtés olarak da tanımlanırlar. Hükümetin icracı ve siyaseten sorumlu kanadına tanınan bu düzenlemeler, başbakan tarafından çıkarılıyorsa Les décrets simples, bakanlıklar tarafından çıkartılırsa Les arrêtés ministériels, özerk bölge yönetimleri tarafından çıkartılmışsa Les arrêtés préfectoraux olarak adlandırılır. Düzenleyici işlemlerin yargısal denetimi Danıştay tarafından sağlanır.

Fransız idari sisteminde kararnamelerin çıkarılabilmesi ve etkin bir şekilde işletilebilmesi hem yürütmenin hem de yasamanın aynı siyasi partiden kurulması halinde mümkün olmaktadır. Buna mukabil "Kohabitasyon (Birlikte Ikamet)" dönemlerinde siyasi rekabet nedeniyle yasamanın daha öne çıkması yüzünden, yürütmenin gerilediği ve icracı karar alma yeteneğinin zayıfladığı görülmektedir (Elgie, 2010: 44-45). Fransız siyasal geleneğinde görülen ve görülme olasılığı oldukça yüksek olan Kohabitasyonlar, yarı başkanlık sistemlerinin en büyük handikaplarıdır. Bu handikabın çözülmesi içinde cumhurbaşkanına meclisi feshetme yetkisi tanınarak yürütmenin etkin ve icracı olabilme yolu açılmak istenmiştir.

Yarı başkanlık sisteminin bir başka özgün örneğini oluşturan Finlandiya'da ise yasama ve yürütme arasındaki ilişkiler 1999 yılında yapılan yeni anayasayla yeni bir sürece girmiştir. 1919'da bağımsızlığına kavuşmasından yaklaşık seksen sene sonra rejim değişikliğine giden Finlandiya, istikrarlı demokrasi ve etkin hükümet kavramı çerçevesinde tamamen kendi dinamiklerine uygun bir yönetim modeli benimsemiştir (Telli, 2010: 239). Bu modelin ilk basamağını oluşturan istikrarlı demokrasi kavramı Fin parlamentosunun tekilci yapısından ve anayasadaki gücünden kaynaklanır (Finlandiya 1999 Anayasası, md.3) (Finland Presidency, 2020). Etkin hükümet kavramı ise modelin ikinci ve tamamlayıcı kısmını oluşturan iki başlı yürütme makamına vurgu yapar. 1999 Anayasa değişikliğiyle birlikte cumhurbaşkanının doğrudan ve altı yıllığına halk tarafından seçilmesi sağlanarak yürütme erki iki başlı bir yapıya kavuşturulmuştur. Yürütmenin ve devletin başı olarak cumhurbaşkanının siyasi sorumluluğu bulunmaz. Buna mukabil Fransa'da olduğu üzere parlamentoya karş1 sorumluluk Hükümetin diğer kanadını oluşturan başbakan ve bakanların üzerindedir (Telli, 2010: 243). Fin hükümet 
sisteminin özgünlüğü bu noktada göstermektedir. Gerek parlamenter sistemlerde gerekse de yarı başkanlık sistemlerinde görülen en çok oy alan siyasi partinin temsilcisi veya genel başkanı Finlandiya'da başbakan olarak atanmaz. Anayasaya göre cumhurbaşkanı, başbakanı atamadan önce parlamentoda temsil edilen siyasi parti grupları hükümetin programı ve kompozisyonu hakkında görüşmelerde bulunur. Cumhurbaşkanı bu görüşmelerin sonucunda meclis başkanına danışarak parlamentoyu başbakan adayı hakkında bilgilendirmek durumundadır (Finlandiya 1999 Anayasası, md. 61). Söz konusu işlemler yapıldıktan sonra başbakan, parlamento salt çoğunluğunu alarak atanır. Gerekli çoğunluk sağlanmazsa aynı usul yenilenir. Yine bir sonuç ç1kmazsa üçüncü oylamada parlamentonun en çok oy verdiği kişi başbakan olarak atanmak durumundadır (Telli, 2010: 246). Buradan anlaş1lacağı üzere hükümetin icracı ve sorumlu kanadını oluşturan başbakan cumhurbaşkanının tercihinden çok parlamentonun tercihine göre belirlenebilmektedir. Başbakan atandıktan sonra bakanlar da yine başbakanın önerisi üzerine cumhurbaşkanı tarafından atanmaktadır. Böylece parlamento kendisiyle uyumlu bir hükümetin kurulmasını sağlamış olur.

İstikrarlı demokrasi ve etkin hükümet modeli sadece yasama ve yürütme arasındaki ilişkilerde kurgulanmamıştır. Yürütmenin kendi içinde de aranan ve istenen bir model olarak kendisini göstermektedir. Fin yürütme sistemi içinde cumhurbaşkanı ve başbakanın görev alanları farklıdır ve her ikisi de ayrı ayrı düzenleme yapma yetkisine sahiptir. Anayasanın 58. maddesine göre cumhurbaşkanı öncelikle hükümetin genel siyasetini gözetir. Başbakan ve bakanlar kurulu tarafından önerilen politikalar cumhurbaşkanı politikalarıyla uzlaşı içinde olmak durumundadır. Eğer cumhurbaşkanı tarafindan konulan politikalar hükümetin diğer kanadıyla uyuşma göstermezse başbakan bu durumu parlamentoya raporlar bildirebilir. Böylece parlamento cumhurbaşkanı ile başbakan ve kabinesi ile aracı konumu elde etmiş olur. Bununla birlikte yine aynı maddeye göre başbakan ve kabinesinin istifa etmesi durumunda, cumhurbaşkanı kendi iradesiyle yürütme politikalarını icra edebilir.

Görev ayrımı bakımından cumhurbaşkanını yetkilerinin atama konularında genişletildiği görülmektedir. Yüksek yarg1 organı üyeleri, üst düzey sivil ve askeri kamu görevlilerinin atanması doğrudan cumhurbaşkanının yetki ve sorumluluğu dâhilindedir. (Republicens President, 2019). İlaveten ülkenin dış politika tercihlerinde de cumhurbaşkanı tam yetkilidir. Ancak bu yetkinin bakanlar kurulu ile birlikte yürütülmesi anayasal bir zorunluluktur (Finlandiya 1999 Anayasas1, md. 93) (Finland Presidency, 2019).

Anayasa, cumhurbaşkanı ve başbakana kendi görev alanlarına giren konularda kararname düzenleme yetkisi vermiştir. Anayasanın 80. maddesine göre kararname yetkisi ancak anayasa veya kanunla düzenlenen konularda verilebilir. Eğer kanunlarda kararname çıkarma yetkisi verilmiş ancak bu yetkinin kimin kullanacağı açıkça belirlenmemişse hükümetin ortak kararnamesi olarak kabul edilir (Şen, 2005: 257). Cumhurbaşkanının çıkardığı kararnamelere Tasavallan Presidentin Asetus (Presidental Decree-Başkanlık Kararnamesi) adı verilir (Finlex Data Bank, 2020). Cumhurbaşkanı kararnameleri Anayasada belirtilen hak ve özgürlükler ile kanunda açıkça tanımlanmış düzenlemeler alanında yapılamaz. İlaveten cumhurbaşkanı kararnamelerinde düzenlemenin gerekçesi de açıkça belirtilmelidir. Buradan Tasavallan Presidentin Asetus'ların gerekçeli bir düzenleme olduğu anlaşılabilir. Başbakan ve kabinesine verilen kararname yetkileri ise genel olarak Alemmanasteinen säädös (Governmental decree,act, statue-Hükümet Kararnameleri) başlığı altında tanımlanır. Hukuk normları hiyerarşisinde üçüncü sırada yer alan bu kararname biçimleri başbakan kararnamesi, bakanlar kurulu kararnamesi, bakanlık kararnamesi ve yerel yönetim kararnameleri olarak sıralanır ve her biri farklı adlandırılır (Finlex Data Bank, 2020). Söz konusu kararnamelerin de tıpk1 cumhurbaşkanlığı kararnamelerinde olduğu üzere gerekçeli olarak çıkarılması, açıkça tanımlanmış bir yetki kanunundan kaynaklanması gerekir. Aksi halde bu kararnamelerin de geçerli olması mümkün değildir. Finlandiya hukuk sistemi içinde bütün kararnameler mahkemeler ve parlamento tarafindan denetlenirler. 
1999 yılında yapılan yeni anayasayla, seçilmiş ve partili cumhurbaşkanı uygulamasına geçen Finlandiya, yürütme karşısında güçlendirilmiş bir parlamento sistemi benimseyerek ve aynı zamanda başbakan üzerinden hükümeti denetleyecek mekanizmalar kurarak ülkenin yeni rejimini klasik yarı başkanlık sisteminden uzaklaştırmış, parlamentarizm ile yarı başkanlık sistemi arasındaki bir yere oturtmuştur (Aslan, 2015: 60). Cumhurbaşkanına yürütmenin baş1 olmasını sağlamakla birlikte yetkilerinin geniş ölçüde kısıtlanarak, çifte denetim içine alınması Finlandiya yönetim sistemini özgün bir noktaya getirmesi bakımından önemli bir gelişmedir. Hiç kuşkusuz Fin yönetim sistemindeki bu değişimin sebebi geçmiş yıllarda yaşanan erkler arasındaki gerilimleridir. Özellikle Kekkonen dönemi, Fin siyaseti içinde erkleri arasında çatışmaların yaşandığ 1 ve zaman zaman cumhurbaşkanının yetkilerini aştığı suçlamalarının yoğun olduğu bir dönem olarak anılır (Paloheimo, 2001: 98-99). 1987 y1lında yapılan düzenlemeyle cumhurbaşkanının halk eliyle seçilmesi sağlanarak bu krizin önüne geçilmek istenmiştir. Ancak ilk seçimlerde yaşanan krizin de buna engel olması yüzünden köklü bir değişim zorunlu hale gelmiş, bunun sonucunda yeni sistem ihtiyacı kendiliğinden doğmuştur.

Geçen yirmi sene içinde Fin yönetim sistemi içinde yürütme yasama arasındaki ilişkiler anayasal hükümlerle belirli bir denge içine sokulmuş, cumhurbaşkanının yetki ve meşruiyet sorunları bir nebze olsun giderilebilmiştir. Buna mukabil Fransız yönetim sistemi içinde yer alan kohabitasyon tehlikesi Fin yönetim sistemi içinde de mevcuttur. Cumhurbaşkanının partisinin mecliste hükümet kuracak çoğunluğa ulaşamaması sonucunda hem yürütme içinde hem de yasama ile olan ilişkilerde büyük bir uzlaşı kültürünün bulunması gerekir.

Tablo 1: Seçilen Ülke Örneklerinde Kararnameler

\begin{tabular}{|c|c|c|c|c|}
\hline $\begin{array}{l}\text { Ü } \\
\mathbf{L} \\
\mathbf{K} \\
\mathbf{E}\end{array}$ & $\begin{array}{l}\text { BİRINCI KADEME } \\
\text { KARARNAMELER } \\
\text { (Yasa gücünde } \\
\text { kararnameler) }\end{array}$ & $\begin{array}{l}\text { İKİNCI KADEME } \\
\text { KARARNAMELER } \\
\text { (Tüzük türevi } \\
\text { kararnameler) }\end{array}$ & $\begin{array}{l}\text { ÜÇÜNCÜ KADEME } \\
\text { KARARNAMELER } \\
\text { (Yönetmelik türevi } \\
\text { kararnameler) }\end{array}$ & $\begin{array}{l}\text { DÖRDÜNCÜ } \\
\text { KADEME } \\
\text { KARARNAMELER }\end{array}$ \\
\hline \multirow[b]{2}{*}{ 争 } & $\begin{array}{l}\text { Executive } \\
\text { Legislations: }\end{array}$ & $\begin{array}{l}\text { Presidential } \\
\text { Directives }\end{array}$ & - & - \\
\hline & $\begin{array}{l}\text { 1.Executive Orders } \\
\text { 2.Regulations } \\
\text { 3.Presidential } \\
\text { Memoranda }\end{array}$ & $\begin{array}{l}\text { 1.Presidential } \\
\text { Determination } \\
\text { 2.Presidential } \\
\text { Proclamation }\end{array}$ & & \\
\hline$\underset{\pi}{3}$ & Ukaz (Ukase) & $\begin{array}{l}\text { Postnanovlenie } \\
\text { (Nocтановление- } \\
\text { Resolution) }\end{array}$ & $\begin{array}{l}\text { Rasporyazheniye } \\
\text { (распоряжение- } \\
\text { Ordinance) }\end{array}$ & - \\
\hline 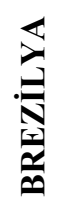 & $\begin{array}{l}\text { Medida Provisória } \\
\text { (Provisional Measures, } \\
\text { Geçici Tedbir) }\end{array}$ & - & - & - \\
\hline
\end{tabular}




\begin{tabular}{|c|c|c|c|c|}
\hline 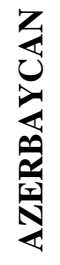 & $\begin{array}{l}\text { Ferman (Presidential } \\
\text { Order- Cumhurbaşkanı } \\
\text { Kararnamesi) }\end{array}$ & $\begin{array}{l}\text { Serencam (Order- } \\
\text { Emirname) }\end{array}$ & - & - \\
\hline 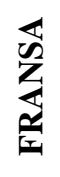 & $\begin{array}{l}\text { Décrets lois (Statuary } \\
\text { order-Yasa Gücünde } \\
\text { Emirler) }\end{array}$ & $\begin{array}{l}\text { Les Ordonnances } \\
\text { (Rule by Decree- } \\
\text { Kanun Hükmünde } \\
\text { Kararname) }\end{array}$ & $\begin{array}{l}\text { Normes Réglementaire } \\
\text { (Regulations- } \\
\text { Düzenleyici Isslemler) }\end{array}$ & $\begin{array}{l}\text { 1.Les décrets simples } \\
\text { 2.Les arrêtés } \\
\text { préfectorau }\end{array}$ \\
\hline 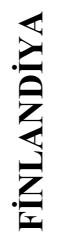 & - & $\begin{array}{l}\text { Tasavallan } \\
\text { Presidentin Asetus } \\
\text { (Presidental Decree- } \\
\text { Başkanlık } \\
\text { Kararnamesi) }\end{array}$ & $\begin{array}{l}\text { Alemmanasteinen } \\
\text { säädös (Governmental } \\
\text { decree, act, statue- } \\
\text { Hükümet } \\
\text { Kararnameleri) }\end{array}$ & - \\
\hline
\end{tabular}

\section{SONUÇ}

Kararname yetkisi günümüz modern devletlerinin yürütme erkinin vazgeçemediği bir uygulama biçimidir. Doğrudan başkan veya hükümet tarafından çıkartılan kararnameler yürütme erkine verilmiş olan politika üretme, icrai karar alma ve düzenleme yapabilme görev ve yetkisinin bir parçası olarak görülmektedir. Bu yönüyle kararnameler hem idarenin bir parçası hem de siyaset yapmanın bir yöntemi olarak görülmektedir.

Yürütme erkinin ayrılmaz bir enstrümanı olarak kararnameler, aynı zamanda Anayasa ve idare hukukunun da inceleme konusudur. Anayasa ve kanunlara dayanarak çıkartılan kararnameler bu yönüyle hukuk normları hiyerarşisinde yerini almaktadır. Dolayısıyla kararnameler, ülkelerin hukuk kurallarının bir parçası olarak değerlendirilirler ve denetlenirler. $\mathrm{Bu}$ denetim ise yargı erki tarafindan sağlanır. Yargının denetleme alanı ise genellikle anayasa ve kanunlara uygunluk ve yetki aşımı olup olmadığı çerçevesindedir.

Başkanlık rejimiyle yönetilen ülkelerde kararnamelerin çok fonksiyonlu ve sayıca çeşitli olduğu görülmektedir. Sert kuvvetler ayrılığıyla erklerin birbirlerinden ayrıldığı bu rejimlerde kararnamelerin, yasama erkine karşı bir denge unsuru olduğu da tespit edilmiştir. Dolayısıyla başkanlık rejimlerinde kararnamelerin içeriği ve etkinlik alanı da geniş tutulmuştur. Doğrudan kural koyma, mevcut bir yasal düzenlemenin nasıl uygulanacağını belirtme, yasal düzenlemenin yapılmadığı alanlardaki boşluğu doldurma ve üst düzey kamu görevlilerinin atanması gibi konular sıklıkla kararnameler tarafından düzenlenmektedir. Söz konusu ülkeler arasında ABD başı çekmektedir. Kuvvetler ayrılığı ilkesinin oldukça sert uygulandığı ABD’nde başkana tanınan kararname yetkisi erkler arasında dengenin sağlanması için sayı ve çeşitlilik bakımından fazladır. Benzer yaklaşım Azerbaycan ve Rusya'da da görülmektedir. Şeklen yarı başkanlık sistemi olarak tanımlanan ancak uygulamada güçlü bir başkanın bulunduğu her iki ülkede de kararnamelerin sayı ve işlevselliği görüntü bakımından çokluk göstermektedir. Bununla birlikte Brezilya'da başkana tanınan kararname yetkisi hem sayıca az hem de işlevsel olarak düşüktür. $\mathrm{Bu}$ durumdan anlaşılan şey daha düşük profilli bir sistem tercihinin yapılmasıdır.

Meseleye yarı başkanlık sistemi çerçevesinden bakıldı̆̆ındaysa ilk göze çarpan şeyin kararnamelerin etkinlik alanının daha dar olduğudur. Başkanlık rejimlerinden farklı olarak bu tip rejimlerde kararnameler, anayasa ve kanunlar dışında kalan alanlarda düzenlenebilmektedir. Dolayısıyla bu sistemlerde kararnamelerin kural koyma veya boşluk doldurma biçiminde 
kullanıldığ1 söylenebilir. Bundan başka kararnamelerin olağan ve olağanüstü dönemler olmak üzere iki aşamada kullanıldığı da tespit edilmiştir. Olağan dönemlerde bu kararnameler son derece sınırlı olarak üst düzey kamu görevlilerinin atanması, Anayasa ve kanunlarda açıkça belirtilmeyen konularda çıkarılabilirken, geniş anlamıyla ancak olağanüstü dönemlerde ve olağanüstü dönemin devam ettiği süre içinde kullanılabilmesidir. Üstelik olağanüstü dönemin sona ermesi durumunda bu yetkinin mutlaka kanunlaşması gerekir. Fransa'da bu durum açıkça görülebilmektedir.

Yarı başkanlık rejimlerinde yürütmeye verilen kararname yetkisinin hem başkana hem de bakanlar kuruluna ayrı ayrı verildiği tespit edilmiştir. Başkanlık rejimlerinde bu yetkinin yalnızca başkan tarafından kullanıldığı düşünüldüğünde, yarı başkanlık sistemlerinde kararname yetkisi ikili hükümet yapısı anlayışı gereği çift taraflı olarak kullanılabildiği açıktır. Gerek başkan gerekse de başbakan tarafından kullanılan bu yetkinin sınırları ve çerçevesi de yasama veya yargi tarafindan belirlenir.

Sonuç olarak, başkanlık ve yarı başkanlık sistemlerinde hükümete ve hükümetin başı olan başkana tanınan kararnameler, parlamenter sistemden daha farklı bir anlama sahiptir. Parlamenter rejimlerden farklı olarak, tamamlayıcı bir hukuk olmasının yanı sıra belirleyici ve norm koyucu bir işlev üstlenmektedirler.

\section{Araştırma ve Yayın Etiği Beyanı}

$\mathrm{Bu}$ çalışma bilimsel araştırma ve yayın etiği kurallarına uygun olarak hazırlanmıştır.

\section{Yazarların Makaleye Katkı Oranları}

Birinci yazarın makaleye katkısı \%50, İkinci yazarın makaleye katkısı \%50'dir.

\section{Çıkar Beyanı}

Yazarlar açısından ya da üçüncü taraflar açısından çalışmadan kaynaklı çıkar çatışması bulunmamaktadır.

\section{KAYNAKÇA}

AJGM, S. (1981). The characteristic features of the civil law, The Comparative and International Law Journal of Southern Africa, Vol.14, No. 2 (7), 196-207.

Aliefendioğlu, Y. (1992). Anayasa yargısı açısından anayasada olağanüstü yönetim usulleri. Anayasa Yargısı Dergisi, 9, 411-434.

Aliyev, C. (2010). Azerbaycan anayasal yargı sisteminde şikâyet denetim usulü: Anayasa şikayeti. Yayınlanmamış yüksek lisans tezi, İstanbul: Marmara Üniversitesi, Sosyal Bilimler Enstitüsü.

Ando, C. (2013). The origins and import of republican constitutionalism. Cardozo Law Review, 34, 917-935.

Aslan, V. (2015). Son anayasa değişiklikleri 1şığında Finlandiya hükümet sistemi. TBB Dergisi, 119, 35-61.

Avc1, A. (2014). İngiliz hukukunda mandamus (mandatory order) ilkesi, Hacettepe Hukuk Fakültesi Dergisi, 4 (2), 165-180.

Azerbaycan 1995 Anayasası. [Çevrim-içi: http://www.anayasa.gen.tr/azerbaycan-aleskerli.htm], Erişim Tarihi: 06.01 .2020

Berkarda, K. (2000). Amerika'da idare hukuku var mı?. İdare Hukuku ve İlimleri Dergisi, 13 (1), 88-107.

Brezilya 1988 Anayasası. [Çevrim-içi: https://www.constituteproject.org/constitution/Brazil_2014.pdf], Erişim Tarihi: 05.01.2020.

Carey, M. P. (2012, July 18). Midnight rulemaking. (R42612). [Available online at: https://fas.org/sgp/crs/misc/R42612.pdf], Retrieved on January 05, 2018. 
Clifford L. L., Vaughan, J. E., \& Baker, C. E. (1944). Presidental executive orders numbered 1-8030-1862-1938. 1, USA: Archives Publishing Company.

Chu, V. S., Garvey, T. (2014, April 16). Executive orders: issuance, modification and revocation (RS20846), [Available online at: https://fas.org/sgp/crs/misc/RS20846.pdf], Retrieved on January 01, 2018.

De Paula, F. (2016). Does Brazil have a legislative policy?. The Theory and Practice of Legislation, 4 (3), 329-353.

Dirk, B. R. (2007). The executive branch of federal government. USA: ABC Clio Press.

Elgie, R. (2010). Semi-presidentialism, cohabitation and the collapse of electoral democracies: 1990-2008. Government and Opposition, 45 (1), 29-49.

Ekinci, E. (2016). Devrimden günümüze Fransız siyasal sisteminin evrimi. Kırıkkale Üniversitesi Sosyal Bilimler Dergisi, 6 (1), 149-173.

Erdem, K. (2017). Yarı başkanlık ya da süper başkanlık; Rusya Federasyonu örneği. Gökçimen, S. (Ed.) Karşılaştırmalı hükümet sistemleri: Yarı-başkanlık sistemi, 6, (ss.185-230), Ankara: TBMM Araştırma Hizmetleri Yayınları.

Finland Presidency. (2019, Novamber 03). Finlandiya 1999 anayasas1. [Available online at: https://www.finlex.fi/en/laki/kaannokset/1999/en19990731.pdf], Retrieved on Novamber 03, 2019.

Republicens President. (2019, September 20), [Available online at: https://www.presidentti.fi/sv/presidentinstitutionen/beslutsfattande/], Retrieved on September 20, 2019.

Finlex Data Bank. (2020, November 21). [Çevrim-içi: https://www.finlex.fi/en/laki/kaannokset/], Retrieved on November 21, 2020.

Fransa 1958 Anayasası. [Çevrim-içi: https://www.constituteproject.org/constitution/France_2008.pdf?lang=en], Erişim Tarihi: 07.01.2020.

Gözler, K. (2000). Türk anayasa hukuku dersleri. Bursa: Ekin Yayınevi.

Gözler, K. (2003). Anayasa hukukuna giriş. Bursa: Ekin Yayınevi.

Gündüz, E. (2007). Yürütmenin düzenleyici işlemleri ve yargısal denetimleri. Gazi Üniversitesi Hukuk Fakültesi Dergisi, XI (1-2), 753-777.

Hacıyev, N. (2009). Başkanlık sistemi ve Azerbaycan örneği. Yayınlanmamış doktora tezi, İstanbul: İstanbul Üniversitesi, Sosyal Bilimler Enstitüsü.

Kuzu, B. (1985). Türk anayasa hukukunda kanun hükmünde kararnameler. İstanbul: Üçdal Neşriyat.

Korte, G. (2017a, January 25). Executive order vs. presidential memorandum: What's the difference?. [Available online at: https://www.usatoday.com/story/news/politics/onpolitics/2017/01/24/executive-order-vs-presidentialmemorandum-whats-difference/96979014/], Retrieved on January 08, 2018.

Korte, G. (2017b, 12 October). The executive action toolbox: how presidents use proclamations, executive orders and memoranda. [Available online at: https://www.usatoday.com/story/news/politics/2017/10/12/how-presidents-useproclamations-executive-orders-and-presidential-memoranda/702751001/], Retrieved on January 08, 2018.

Lenin, V. (1917). Collected works. Moscow: Progress Publishers. [Available online at: http://www.marx2mao.com/PDFs/Lenin\%20CW-Vol.\%2026.pdf], Retrieved on April 05, 2019.

Mehmetoğlu, E. (2010). Azerbaycan anayasasında yürütme erki. Yayımlanmamış yüksek lisans tezi, İzmir: Dokuz Eylül Üniversitesi, Sosyal Bilimler Enstitüsü.

National Archieves (2020, 03 Şubat). [Çevrim-içi: https://www.archives.gov/about/regulations], Erişim Tarihi: 03.02.2020.

Negretto G.L. (2004). Government capacities and policy making by decree in Latin America: The cases of Brazil and Argentina. Comparative Political Studies, 37 (5) (June), 531-562.

Oder, B. E. (2004). AB'de anayasa ve anayasacılı, İstanbul: Anahtar Kitapevi.

Oytan, M. (1982). Fransa'da yürütme organının yetkileri ve güçlü olma nedenleri, Amme İdaresi Dergisi, 15 (1), (3), 85-104.

Paloheimo, H. (2001). Divided executive in finland from semi-presidential to parliamentary democracy, Elgie, R. (Ed.) Divided government in comparative perspective, (pp.86-105). UK: Oxford University Press. 
Relyea, H. C. (2008, November 26). Presidential directives: background and overview. [Available online at: https://fas.org/sgp/crs/misc/98-611.pdf], Retrieved on January 05, 2020.

Remington, T. F. (2000). The evolution of executive-legislative relations in Russia since 1993. Slavic Review, 59 (3), 499-520.

Remington, T. F. (2014). Presidential decrees in Russia: A comparative perspective, UK: Cambridge University Press.

Rosenn, K.S. (2009). Separation of powers in Brazil. Duquesne Law Review, 47, 839-870.

Rusya 1993 Anayasası, [Çevrim-içi: http://www.anayasa.gen.tr/rusya.htm], Erişim Tarihi: 05.01.2020.

Saygın, E. (2017). Ölçülülük ilkesine yönelik Türk ve İngiliz idare hukuku yaklaşımı üzerine karşılaştırmalı bir analiz. Ankara Barosu Dergisi, 2, 58-88.

Schwartz, B. (1952). French and Anglo-American conceptions of administrative law. University of Miami Law Review, 6 (3), 433-445.

Solak, M. (2017). Koalisyoncu başkanlık sistemi: Brezilya. Gökçimen, S. (Ed.), Karşılaştırmalı hükümet sistemleri başkanlık sistemi ABD, Arjantin, Azerbaycan, Brezilya ve Nijerya örnekleri, 7, (ss.202-255), Ankara: TBMM Araştırma Hizmetleri Yayınları.

Şen, İ. G. (2005). 1919'dan 2000'e Finlandiya: anayasal ve siyasi gelişmeler. Dokuz Eylül Üniversitesi Hukuk Fakültesi Dergisi, 7 (2), 227-264.

Şencan, H. (2017). Çatışmacı parlamentarizmden melez bir çözüme: Fransa'da yarıbaşkanlık sistemi. Gökçimen, S. (Ed.), Karşılaştırmalı hükümet sistemleri: yarı-başkanlık sistemi, 6, (ss.25-100), Ankara: TBMM Araştırma Hizmetleri Yayınları.

The American Presidency Project. (2020, January 10). [Available online at: http://www.presidency.ucsb.edu/data/orders.php], Retrieved on January 10, 2020.

The Russian Governments. (2020, January 5). [Available online at: http://government.ru/en/docs/, Retrieved on January 5, 2020.

Telli, K. (2010). Finlandiya'nın 1999 anayasasıyla öngörülen hükümet modeli. Türkiye Adalet Akademisi Dergisi, Y11:1, 2 (7), 237-255.

Vie Public. (2020, January 5). [Available online at: http://www.vie-publique.fr/decouverteinstitutions/institutions/administration/action/voies-moyens-action/qu-est-ce-qu-ordonnance.html], Retrieved on January 5, 2020.

World Future Fund. (2018, January 5). [Available online at: http://www.worldfuturefund.org], Retrieved on January 5, 2018.

Yücel, B. (2003). Yarı-başkanlık sisteminin hükümet modeli üzerine karşılaştırmalı bir çalışma: Fransa modeli ve komünizm sonrası Polonya. Ankara Üniversitesi Hukuk Fakültesi Dergisi, 52 (4), 335-364. 


\section{Extended Summary}

\section{Some Examples of Decree Implementation in Presidency and Semi-Presidency Regimes: A Comparative Analysis}

On April 16, 2017, Turkey switched to a new system of governance called the presidential system of government.This referendum represents a transformation from a nearly hundred-year-old parliamentary system of government to a single executive system.The presidential system of government, briefly called the presidential system in the literature of public administration, is a system that directly makes the president the only competent and only responsible body of government. Although it is a new system for Turkey, there are many examples of this type of government system in the world. While some countries give executive power to the president directly, in some countries, the president is strong, but shares his powers with the government, which comes out of parliament and consists of the prime minister and the council of ministers. The systems in which the government is directly connected to the president are defined as the presidential system, while the systems which shares it with the council of ministers coming out of parliament are defined as the semi-presidential system.Each country governed by presidential or semi-presidential systems constructs and implements its own unique executive system within the framework of its own needs and management traditions.However, the most obvious common point of this system seen in the world is that it shows itself in the powers granted to the president.It is clear that the most important authority granted to the president in presidential or semi-presidential systems is the "Decree Power".Essentially a constitutional authority, the decree is an important authority that gives the president the authority to regulate, make executive decisions and implement executive actions. The essence of decree powers is to make executive functional in state administrationand operate public administration more effectively and efficiently. In modern democracies, decrees are expected to derive from constitutional powers.However, a process clearly called a decree cannot be expected to exist in the constitutions.In such cases, the process we call a decree is seen as a "traditional procedural" legal process that does not clearly find its source in the constitutions.

The aim of this study is to present in a comparative perspective the forms and principles of decree power granted to the president in the current presidential or semi-presidential systems in the world.The hypothesis of the study is that in presidential and semi-presidential regimes, the decree power granted to him is varied and categorized in terms of form and content, since the president is the sole responsible for the executive power.

As an instrument most commonly used in the regulatory proceedings of the administration, decrees appear to have originated from a different source in the civil law legal system and in the Anglo Saxonlegal systems. In the civil law system, decrees are used for ordinary or extraordinary situations. Decrees issued in ordinary cases are more often considered as concrete rules or forms of application governing how a law will be applied, within what principles it will be executed. In ordinary periods, the parliament gives the government or the head of government the ordinance power, and then the decree issued is again enacted by the parliament.It is a general rule that decrees made in ordinary periods consist of five basic elements: authority, subject, form, audit and other considerations.

The power and effectiveness of decrees issued during extraordinary periods are again regulated according to the rules applicable within the constitutional legislation. The most important difference between extraordinary decrees and the other is that regulations temporarily allow the partial or complete cessation of fundamental rights and freedoms or the introduction of certain obligations for citizens are made within extraordinary decrees. In this context, states of emergency, martial law, leeveen masse and war must be governed by these decrees. However, it is also necessary that the decrees of the state of emergency comply with the terms and principles of the state of emergency.In terms of procedure and form, emergency decrees are expected to 
comply with the principles of ordinary decrees. On the other hand, state of emergency decrees do not have constitutional control.The only supervision mechanism of decrees to be issued in state of emergency is the legislature.The legislature may narrow the duration and scope of such decrees or determine their merits.

In theory, the Anglo-Saxon legal system also has the same purpose as civil law on decree. However, the Anglo-Saxon tradition had different expectations in practice regarding the decree. As is known, in the Anglo-Saxon legal system, the rules of law do not consist solely of general and abstract regulations that arise as a result of legislative activity. It also includes solutions of concrete events arising directly from the practices of social life.In this system, judicial decisions and executive practices are another method of producing law.In the AngloSaxon system, administrative law emerged as a result of the growth of public services, and had an understanding of all matters outside of criminal and private law. Over time, it has expanded to cover all areas of public administration and has turned into a mechanism that checks, directs and controls public and private organizations operating in all areas which are today considered public service. Particularly with the development of American administrative law, regulatory, mediator, stability provider and enforcement process of legal systematics has shown itself; however, it has a narrow concept. Administrative law, which has found a unique place in the general legal system, has not shifted to a different area as in the civil law system.Just like the private sector, administrations are abided by the rules of general law in the general economic and social order and are subject to the supervision of a holistic judicial system in all disputes.Within the general characteristic of the system, the judiciary has a wide range of actions such as making various concrete regulations as cancelling, prohibiting or issuing coercive orders when it deems necessary and making rules. The fact that the judiciary, as in other matters, is so effective in the field of administrative law has led to the definition of Anglo-Saxon administrative law as a judicial administrative legal system.

The study is generally based on secondary source compilation.Legal processes and sanction powers of presidential decrees are compared and explained within the framework of selected country examples. Striking decree examples from the USA, Russia, France, Latin world were compared with each other.

The above-mentioned examples were selected by taking into account the functioning of presidential decrees in these countries, their status before the law and constitution, and capacity of authority.

Decree power is a form of practice that the executive power of modern states cannot abandon.Decrees issued directly by the president or the government are considered part of the duty and authority to produce policies, make executive decisions and regulate granted to the executive authority.In this aspect, decrees are seen as both part of the administration and as a method of doing politics.In countries governed by a presidential regime, decrees seem to be multi-functional and diverse in number. In these regimes, where powers are strictly separated from each other, decrees are found to be an element of balance against the legislative power.Therefore, in presidential regimes, the content and activity scope of decrees were also kept wide.Issues such as direct rule-making, specifying how to implement an existing legal regulation, filling the vacuum in areas where no legal regulation is made, and the appointment of senior public officials are often regulated by decrees.

Considering the issue from the perspective of the semi-presidential system, the first striking point is that the effectiveness of decrees is narrower.Unlike presidential regimes, decrees in such regimes can be regulated in areas outside the constitution and laws. Therefore, in these systems, it can be said that decrees are used in the form of rulemaking or filling vacuum. Furthermore, it was determined that the decrees were used in two stages: ordinary and extraordinary periods.In ordinary periods, these decrees can be issued on extremely limited terms such as appointment of 
senior public officials and issues not explicitly stated in the constitution and laws, while in a broad sense they can only be used in extraordinary periods and during the duration of the extraordinary period.Moreover, this authority must be enacted if the extraordinary period ends. 